\title{
Percussion considerations of the Passion of the Lord
}

Among many musical genres, one of the most important places is passion. The contemplations of the Passion of Christ through various means of expression have for many years been centered around two works by Johann Sebastian Bach: Passion according to St. John and according to St. Matthew - which are the original and deep musical interpretations of this genre. In the twentieth century the greatest composers referenced to this tradition, among them Krzysztof Penderecki (Passio et mors Domini Nostri lesum Christi secundum Lucam, 1966), Paweł Mykietyn (The Passion according to St. Mark, 2008), expanding arsenal of musical means of expression to the level of 20-age-old expression. Contemporary composers introduced to the passion music, among others. percussion instruments, whose sound from the dawn of history was connected with various forms of sacrum. This article deals with Carminie Crucis by Stanisław Moryto - a work in which the sounds of elaborate percussion sets talk about the passion of Jesus Christ. The author - active drummer, apart from the analysis of individual parts of the cycle, devotes much attention to executive issues, presenting readers with ready technical and interpretative solutions.

Key words: passion, Stanisław Moryto, drums, road.

Percussion music has been associated with various forms of sacrum for ages. It appeared in the farthest corners of the world, with the help of rhythmic instruments such as drums, knockers, rattlesnakes the old man could tame the forces of nature, the power of his own intellect, and the imagination transformed into deities. In the animist beliefs in which the central figure is the shaman, the drum appears not as an instrument, but as a powerful power tool for contact with spirits, 
Theology of beauty tribal consciousness ... Thus it fulfills a similar function to the escaping smoke into heaven. Through the power of the sounds, it enables dialogue with the characters of the overreliant world, introverted (meditation) or extroverted (ecstatic dance, ritual orgies), it unites matter with spirit, object with subject ${ }^{1}$. The drum in shamanism is the breath of God, the voice of the forest ${ }^{2}$. He accompanies the songs by generating trance states, often backed up by potions made out of plant neogens ${ }^{3}$ - psilocybin mushrooms used by the Mazatkas ${ }^{4}$, penguins used by Huichola Indians, DMTs used in inhalation or in infusion form by the Indians of the Amazon Basin.

Every religious system evokes an image of eternity through specific spiritual practices supported by various forms of music. Numinotry experience is often associated with the original sound energy, which in percussion music finds the fullest expression of accomplishment. The percussion sacrum appears practically in all the religious traditions of the world. In the context of this statement, the aspect of percussion music seen through the prism of Christianity is the most interesting.

The written and spoken word of Christ has always been correlated with art - the language that the message was sent to the masses through its universal character. Music, as the language of tradition, described in extraordinary ways the life and death of the Savior. In the Middle Ages, the musical image of the Passion of the Lord was the core of the Mysteries. The best examples are Old Polish processions of Holy Week, in which music - often limited to the sounds of percussion wooden pegs or taken from the tradition of the Eastern simantr symbolizing asceticism, penance - was an expression of profound faith, mortification of body and soul.

The presence of percussion in the art of the Church is of diademic character. On the one hand, it is a divine instrument, mentioned in biblical psalms. Its sounds are praising God, manifesting his greatness:

Praise God in his holy place, praise him in the heavenly vault of his power, praise him for his mighty deeds,

Just as smoke is born from matter, the percussive sound also arises from it. In itself, it is a manifestation of the spirit and has a metaphysical aspect.

An example here is the percussion instrument built from the dried leaves of rainforest plants - waira - used during Ayahuas ceremonies; R. Metzner Ayahuasca - święte pnącze duchów, ed. Okultura, Warsaw, 2013, p. 126.

3

Entheogens are defined as plants containing psychoactive substances. According to various forms of shamanism, they help to communicate with ghosts. 
praise him for all his greatness.

Praise him with fanfare of trumpet, praise him with harp and lyre, praise him with tambourines and dancing, praise him with strings and pipes, praise him with the clamour of cymbals, praise him with triumphant cymbals,

Let everything that breathes praise Yahweh. Alleluia!

Bible, Psalm 150

Percussion instruments such as various knockers, tarts accompanied the Lenten processions, inviting through their sound to repent and meditate on the martyrdom of Christ ${ }^{5}$.

On the other hand, percussion instruments, due to their large volume of sound, were the musical attribute of demonic forces in Christianity. Such a view was captured by medieval Dutch painter Jerome Bosh in his triptych Garden of Earthly Delights, made in oil on board. A detail from this work depicts a demon playing on a drum. It is located in the right wing of a triptych depicting hell.

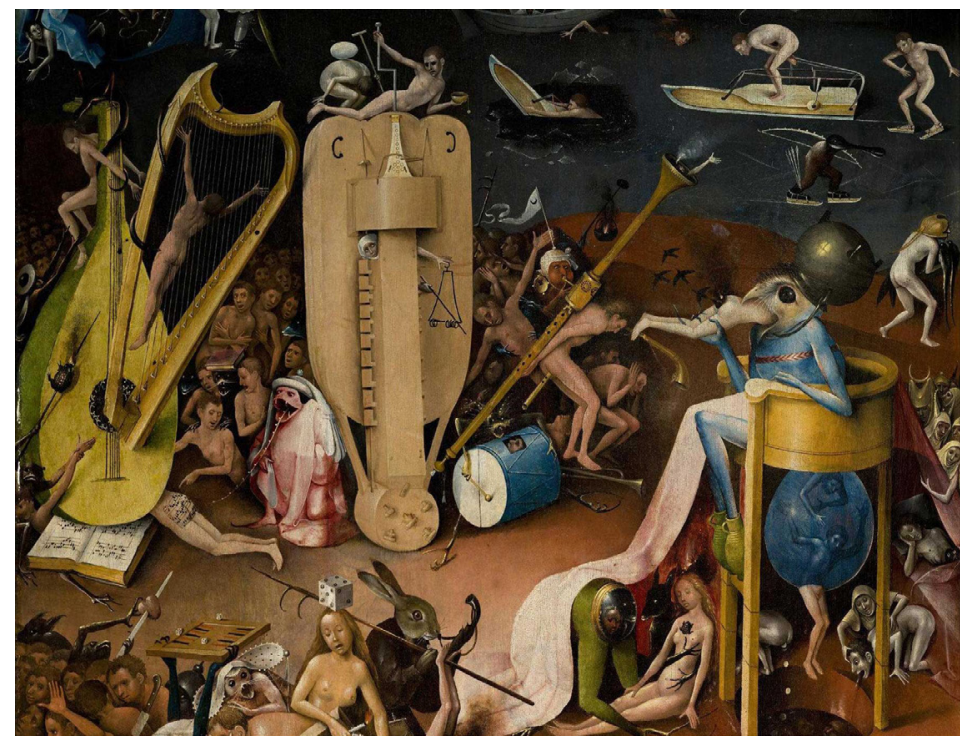

Fig. 1. Hieronymus Bosch, Garden of Earthly Delights.

In the 20th century, these instruments were used. By Krzysztof Penderecki in the composition of Jutrznia (Złożenie Chrystusa do grobu) of 1970. 
Theology of beauty

In many parallitic compositions created by composers in the twentieth century ${ }^{6}$, percussion instruments play an important role, bearing the "ideological burden of work" on their shoulders. However, this is not a leading role - the percussion is used in these compositions as an orchestra. Its sounds create tension in conjunction with the sound of other instruments used in the song. The discovery of the solo percussion possibilities seen through the prism of the Christian parallitial mystery has been fully realized in the creative activities of Stanislaw Moryto and Marius Constant.

These composers introduced percussion into the sacred space, making it a medium of artistic expression standing on par with organs whose "dominion" in the centers of the Christian sacrum seemed to be indivisible ... This paper deals with a great percussion work, now classified as a classics of its genre. - Carmina Crucis Stanisław Moryto. The composition was created in 2000 and is a syncretic work combining poetry, music and visual arts.

\section{Stanislaw Moryto - Carmna Crucis}

Seek out Yahweh while he is still to be found, call to him while he is still near.

Let the wicked abandon his way and the evil one his thoughts. Let him turn back to Yahweh who will take pity on him, to our God, for he is rich in forgiveness; for my thoughts are not your thoughts and your ways are not my ways, declares Yahweh.

The Bible, Is 55, 6-8

The above passage of the Holy Scriptures opens the booklet accompanying Stanisław Moryto's CD Carmna Crucis ${ }^{7}$. The depth of the message of the biblical text is a perfect foretelling of deep, full of spirit and mystery music, gradually discovered in each of the fourteen parts of the work. As it was rightly noted by Krzysztof Lipka:

Carmina Crucis is a religious work, even paraliturgical. It represents a very contemporary religion, to the extent of our time, turning inward

$6 \quad$ Examples of composition: Krzysztof Penderecki Jutrznia (1970), Pasja wg św. Łukasza (1963/66), Henryk Mikołaj Górecki Salve Sidus Polonorum (1997)

7 Stanisław Moryto - Carmina crucis; ed. DUX, 2002, Stanisław Skoczyński drums, Henryk Boukołowski, Magda Teresa Wójcik - recitations 
without drama and emphases. [...] It offers a moment of rest and a slightly elevated mood in a world that is increasingly lacking in such a moment ${ }^{8}$.

The introvert nature of Stanisław Moryto's work is achieved by the sounds of the elaborate percussion instruments, accompanied by the recitations of contemporary poetry - the poem by Andrzej Zieliński, performed by two actors - a woman and a man. The use of percussion as a sound medium for the liberation of mystical and meditative states may seem paradoxical. Multiplexes are usually associated with a high volume of sound, with the uncontrollable energy generated by aggressive rhythm. In the case of the analyzed composition we are Theology of beauty dealing with a completely different situation. Operation of low dynamics, contemplation of individual percussion tones of idiophones, care for the beauty of the sound make each part of the work a kind of song about the individual stages of the redemptive way of Jesus.

Professor of Philosophy of the Fryderyk Chopin University of Music in Warsaw - Jagna Dankowska - writes about it as follows:

The seeming paradox of building silence with the percussion music emphasizes in this particular way the importance of spiritual life, the only effective defense against the outside world, and the path to other areas of metaphysical experience and space, in order to teach the ordering of inner and outer things ${ }^{9}$.

In Carmina we will not find the scream, the bustle of the narrow streets of Jerusalem filled with governmental throngs of crowd. Their place is occupied by the quietness of suffering, collapsing into themselves allowing deep insight into their own interior. The question of knowing one's own self appears in many of the world's religious traditions. I will remind here of Socrates' inscription on the Apollinaan temple in Delphi, - Know Thyself and St. Augustine's maximus - enter into yourself, in the interior of man lives the truth.

However, the contemplative nature of the work does not mean the composer's complete resignation from virtuoso elements. In many parts of the percussion mystery there are rhythmic structures, textural solutions, musical phrases requiring the drummer of extraordinary technical ability necessary to conduct musical narrations. However, the virtuoso remains deliberately hidden so as not to overwhelm the ideological layer of the work. Important aspects of the composition to

8 Source: http://muzyka.onet.pl/klasyka/moryto-carmina-crucis/4twr2; access 17.09.2017, 23.32

9 J. Dankowska, booklet attached to Carmina Crucis; ed. DUX, Warsaw, 2002, p. 36 . 
be discussed before proceeding to the analysis of its non-specific parts are: the topophony of the sound and the motive associated with it. Various parts of the work, known as a station, are distributed in different places in the temple. The drummer goes to the next multiprocessing sets, performing on each of them a specific part of the work. In the literal sense, this wandering is used to change the sound generators and change the acoustics. The sacred space thus becomes equal - next to the percussion and recitals - of the composition of the work, undoubtedly influencing the reception of the work. In a metaphorical sense, the way the drummer makes is on the one hand a symbol of Jesus' Via Dolorosa, and on the other, a symbol of the inner journey of every human being leading to spiritual gnosis, liberation and transformation.

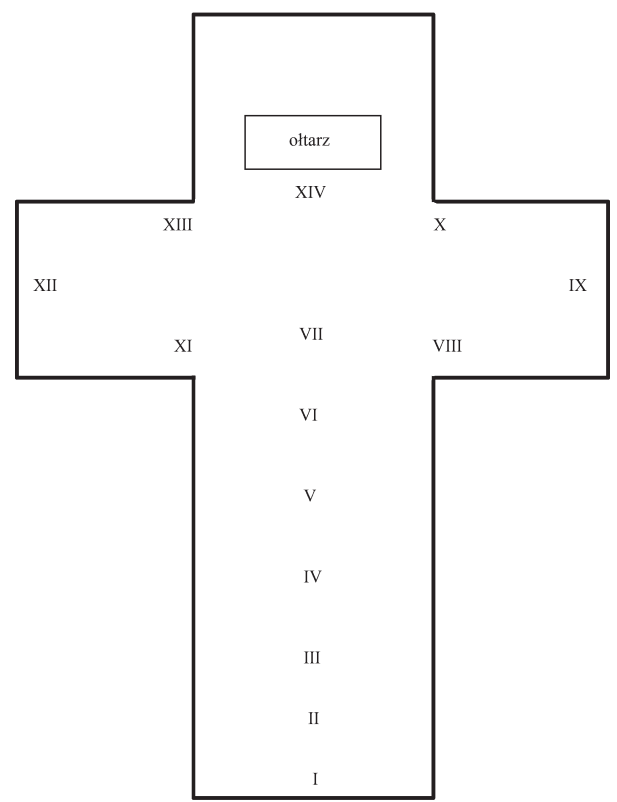

Fig. 2. An example of a church arrangement for the composition of Carmina

Crucis by Stanisław Moryto

\title{
1st Station - Jesus is condemned to death
}

\author{
„Guilty!...” - the judgment has been passed, \\ inquiry continues: \\ Love... Truth... Testimony... - \\ „Could lead to destruction, and we must save \\ the people!"
}


- „It is crucial though not to be defiled”.

„The scheming of the high council, blacmail, slander

Fortune-telling, fears, apprehensions

prophetic dreams...

I stand for the laws of Rome:

Where there is punishment, there must guilt also be!"

„Behold the man!... I am Caesar's servant!...

Take him and crucify, but stay away from... me!"

-,,We know who you are...” - „Answerest

thou nothing?... I find no fuolt in this man!..."

„Hands covered in blood?!... Ah, terrible, ghostly hours!...

The sun is burning!... It's six o'clock... Shadows disappear..."

The Song of the Cross begins with a toccata (Italian toccare - hit) to a set of eleven tuned deep-toned drums supported by the acoustics of the place where the work is performed. The composer draws a drawing of the melody in it, which is performed on marimba in the last part of the cycle. Its interval construction is based on the second messianic modus, built on the successive intervals of small and great seconds. Both the first and the last part of Carmina are characterized by a tight, sexton rhythm. Using the form of toccata, Stanisław Moryto refers to a musical form created in the 16th century, most popular in the Baroque period. Its characteristic features were fast tempo and virtuosity. Both of these elements can be successfully relied upon in the first part of this work. Toccata of Carmine Crucis is a percussive incipit, a kind of foreword that announces later events - physical (here in the sense of hearing heard by musical interventions) and metaphysical (here contemplation of the next stages of the Passion of the Lord). It is characterized by high energy, despite the small dynamic diapazony, the fluidity of the musical phrase.

From the technical point of view, it is important to mention the difficulties associated with the sound of the diaphragm sound in large acoustical space, which may result in lack of musical clarity. This problem can be partially overcome by lightly suppressing the membranes and by applying a medium hardness sticks.

\section{2nd Station - Jesus carries his cross}

O God, so I have but to take this cross?

Does it makes sense to suffer if there are so many other ways?

Look! He has seized the cross with both hands;

He stops at the crossroads, it seems he is awaiting somebody - 
Theology of beauty

Is he a man of sorrow, the propher or incomprehensible God, Who gives his life for man's salvation? -

The music material of the second part of the composition was limited to the sound of tubular bells. The use of this instrument is an obvious reference to the tradition of the use of church bells, dating back to medieval Europe. Drum bells differ from their protoplasts, both the structure and the material they are made of. Campane tubulari ${ }^{10}$ have no heart; sound extraction is accomplished with the use of specially prepared mallets. The free operation of such inducers makes the melody performed on the percussion bells may have more varied characteristics than that performed on church bells. I mainly mean dynamics, varied rhythm, phrase formation. In the analyzed part of Carmina crucis the drummer creates a form of full questions and dialogues, which are musical interpretation of the poetic text.

The metallic, pure sound of the instrument can be read as a symbol of glow. Jesus puts on his shoulders a cross which, as we read in subsequent poetic passages, is a "shame to the Jew". But his suffering is sanctified, proclaims the Kingdom of Light.

The sound of the bells is the opposition to the next part of the composition, dominated by the "remorseful tones" of the wooden bell, angklung and geophone.

\section{3rd Station - Jesus falls the first time}

„(...) He has only fainted, but is still alive...” - ,poor comfort;

Hosts of angels will not come to save him,

They will not fight...” - „give him a good lashing!

It is getting late, the Passover is at hand, hurry up... holy man"

„A friend of publicans!...” - ,,just guzzling wine!...”

- „A glutton and a drunk...” - „Loved by harlots”

- „Use your boot centurion this will give him strenght!...”

- „it is no honour for a soldier to kick a man while he is down;”

- „Move back...!” - „Forgive them Father...

They know not what they do..."

Consuming anger has crept onto their faces...

The guilty ones on Innocent lamb blame...

The scripture must be fulfilled... Father, I give you this cup

$10 \quad$ Italian term for tubular bells. 
As my offering!... I raise it in the air!... I drink it to the last!...

I'm weakening... God, lead me... Give me

a sign!... Give me a sign!...

The third part of the percussion mystery is about the first fall of Jesus under the weight of the cross. The minimalism of the means of expression, manifested by the use of only three small percussion instruments, is inversely proportional to the dramaturgy that builds their sounds. Stanislaw Moryto uses ascetic sounds of wooden bell, angklungu and geophon. The dry tones of wooden idiophones represent reminiscence of the color of semantron or known from the orthodox church of the East. In their original function these instruments called upon the monks to pray - their tradition is older than the tradition of bells ${ }^{11}$.

There are two types of them:

- a metal one, the equivalent of bells. It is a suspended metal plate or a metal, thick rod. The sound is obtained by inducing the instrument to dangle with the help of a metal hammer or metal bat

- a wooden one, in the form of a suspended board from which the sound is extracted by hitting it with a wooden hammer or a wooden stick

In the analyzed part, as mentioned, there is also an angklung. This instrument is made of bamboo tubes placed on a stretcher, tuned in the octave interval. Angklungs appear in Indonesian percussion ensembles, have a symbolic meaning, the subject of which oscillates around such concepts as the harmony of life, the cult of fertility.

The use of exotic instruments in paraliturgical music is a kind of precedent, testifying to the artistic courage of the composer. At the same time, it confirms the principle that percussive, spiritual implications exist above religious or philosophical divisions.

The last bits of the third part of the work are filled with geophonics $^{12}$ - a flat, two-drum drum, with small metal balls in it. In case of changing the angle of the instrument, the balls move one membrane, causing a loud noise - it is the link to the next part of the piece.

11 12th century Antoine's patriarch Teodor Balsamon sees in the simian symbol of the difference between the East and the West. See: J.M. Hussey, The Orthodox Church in the Byzantine Empire, Oxford, 1986, p. 310. 


\section{4th Station - Jesus meets his mother}

Mother?!...

Face to face

A thought and a blink

Two hearts

Suffering

Cross of contempt

Crown of thorns

Mother's

Teardrop

Without a word

The fourth part tells the story of Jesus' meeting with his mother. This is one of the more intimate, counter parts of the work. Meeting with a weary son takes place on two levels:

- humanly/material - here the motif of the suffering mother, who sees an ordeal of his son, is emphasized - the attention of the recipient is directed to the physical pain of Jesus and Mary

- divine / intangible - the suffering of the mother is subordinated to the will of God, who himself seems to die - the attention of the recipient is directed to the soteriological aspect of suffering

The musical and formal structure of this part is based on the vibraphone chord, which interrupts at some time with the sound of chime of Chinese profondo chimes and the chromatic chimes on which the chorus melody of Dolorosa et lacrimabilis es, virgo Maria of the Mass for the Feast of the Seven Sorrows of the Blessed Virgin Mary. The reference to the medieval singing of the Church archaises the discussed part of the cycle by placing it in a separate space-time. So we are dealing with a kind of collision of two epochs - medieval (choral) and contemporary (vibrancy chord). By interpreting this passage on another, symbolic plane, we can hypothesize that the vibraphone party is a musical representation of Jesus, and that the bells are the image of Mary. In this ideological setting, the music of the fourth part of Carmina Crucis is a kind of dialogue between Jesus and his mother; silent dialogue, directed inside.

\section{5th Station - Simon of Cyrene helps Jesus to carry his cross}

They forced me!... A terrible thing! ... To carry the cross with a man, 
Who calls himself the Son of God,

To go arm in arm, side by side, to terrible and watch in fear,

Taking in my arms the innocence or the utmost guilt?...

Avoiding the fall, fighting till the bitter end

Not to let yourself be brought to the ground -

this death with disgust,

The fallen notion for Times immemorial fills

Casting the shadow of a cross - a cross -

a disgrace for a Jew!

And so we go further and further yoked together,

Until it is done and the new day comes

And Love will from the cross descend and

change hearts

Like the water in Cana of Galilee was made wine

The fifth part of Carmina Crucis is designed for membranes with natural skin: bongos, congi, Chinese tom-tomes. Its characteristic feature is polyphonous texture. The use of natural-skinned drums is a kind of musical and ideological regression - the composer refers to this ritual aspect of percussion as I mentioned at the beginning of this work. Characteristic instrumentation forces the performers to induce the sound with hands - the sound is then "more organic", similar to the color of the ritual drums known from the rituals of animistic cults.

\section{6th Station - Veronica wipes the face of Jesus}

Sweltering heat, pressing crowd

Guards in heavy armor

The convict's painful grimace

Snow-white kenchief

And the scream that rises up in one's heart:

- ,he is mine"

- ,and you are mine...”

The sixth part of the work is dedicated to the crotch - metal idiophone in the form of small discs made of thick bronze or brass alloy, whose sound is characteristic "crystalline color". The composer draws the vision of the bloody face of Jesus, which was left on Veronica's sudarium ${ }^{13}$. The overlapping tones, elongated by can arco articulation,

13 Now this relic is called the Sudarium of Manopello; P. Badde, Boskie Oblicze. Catun z Manoppello; wyd. Polwen; Radom, 2006. 
create tones of glow that change the real time and space in the sacral time and the sacral space. The image of Jesus, that miraculously was fixed on canvas, can be interpreted as a symbol of the omnipresence of God, looking at man and showing him the way to follow. The idea of communion of holiness in the earthly world (symbolized in the context analysed part by the Veronica's sudarium) was developed in the apocryphal Gospel according to Thomas, in which Jesus says:

I am the light that is above all. I am Full, Full came out of me, Full came to me. Break the tree, I'm there. Pick up the stone, and you'll find me there.

\section{7th Station - Jesus falls the second time}

“(...) And I am just a warm, not a man... Father,

The night pitch dark and the brim-full cup;

But as the glimmering flame of my lamp burns up

Satan exults in his triumph, the forces of evil are closing in,

Second down your power, your holy mercy

so I could be like a stone cast in the dust

Before the hands of hope carry it away!"

„Wake up, the land of Judah, leave your vacuous dream

Eve - Sarah - Esther, drowned in your sorrows!

Today on all of your roads, as on a furrowed brow,

The kiss of peace the heavens lay"

The second fall of Jesus under the weight of the cross was depicted by the sounds of Chinese, Korean, snare and vibra slap. The composer refers in this section to the construction of passacaglia - a Baroque variation form. It is worth mentioning that Stanisław Moryto treats the instrumental parts in a melodic way, despite the sharp outline of the rhythm. Thus, the color of the sound of the membranes and idiophones is reached, which is achieved by the use of matching sticks. Instrumentation of the fragmented percussion fragmentation of mystery evokes the impression of something inevitable; Impressed by the distant sound of the sound, they seem to be asking: Why is Jesus falling? The answer tells the next fratment of the cycle: God does not fall under the weight of the cross, but descends to the level of man to save him. 


\section{8th Station - Jesus comforts the weeping women}

"Daughters of Jerusalem, why do you weep?...

A new shoot out of the trunk of a fig tree grows

The spring is at the gates

Though the root is old and the trunk rotten, a new branch Will live. Jerusalem grow,

Abide in my love!” “

The eighth song of the cross is dedicated to the xylophone. To perform it requires a four-chip technique, which in the case of playing this instrument is a peculiar problem, bringing many technical difficulties. The composer decided to use the xylophone because of the color of his sound - a sharp, wooden, contrasting to the marimba sound used in the 12 th and 14th stations. The form and content of the part is a musical variation of the epicedium - a funeral literary featuring the praise of the deceased, regret, mourning and consolation. The rich chord based on the second Messianen modus adds to its supreme character, while highlighting the theme in the highest voice.

\section{9th Station - Jesus falls the third time}

He fell... pressed to the ground (a huge cross crashed)

The throng fell silentl - they stand, look, wait) -

He go tup slowly... and clasped the cross in his caring hands

With an eye as bright as the sky, as though from the dust of earth

The most wretched man he lifted up

Drama of 9th Station builds the sounds of the tuned gongs and terraces - a soft sheet of about $2 \mathrm{~m} / 1 \mathrm{~m}$, vibrating by shaking. The sound of this instrument brings to mind the increasing wind and is a peculiar link between the musical phrases of the Burmese gongs. Once again, the color of the instrument is emerging, confirming the principle of naming the cycle with the songs of the cross. The analyzed part dominates contemplation of individual vibrating tones of the metal idiophones.

\section{0th Station - Jesus clothes are taken away}

Up the green path to the top of the hill

Went a man carrying the cross - of truth and love

The king said: 
- Come unto me, all ye that labour,

The lame, the lepers, the blind, the deaf, the dumb,

The por, the publicans, the harlots,

The beggars with their grasping hands in the doorways

And you of little faith, who lack courage -

I am the way and the truth..."

- Said one of the killers:

- „Truth? - Just look

People! - The king is naked!"

The musical content of the 10th station is filled with the cencerros tuned alpine tunes, and Burmese gongs. The slow, spewing phrases of the metal idiophones spawn in the acoustic space bring listeners into the mind of the condemned man, who combines two nature - human and divine. Suffering and humiliation coexist here in an inner way and in trusting in God. Sound interventions are performed with the help of soft batons, which gives the sound of a soft, gentle character.

\section{1th Station - Jesus nailed to the cross}

Three painful bites, Nailed feet and hands O Jesus, remember me, When it is all done!

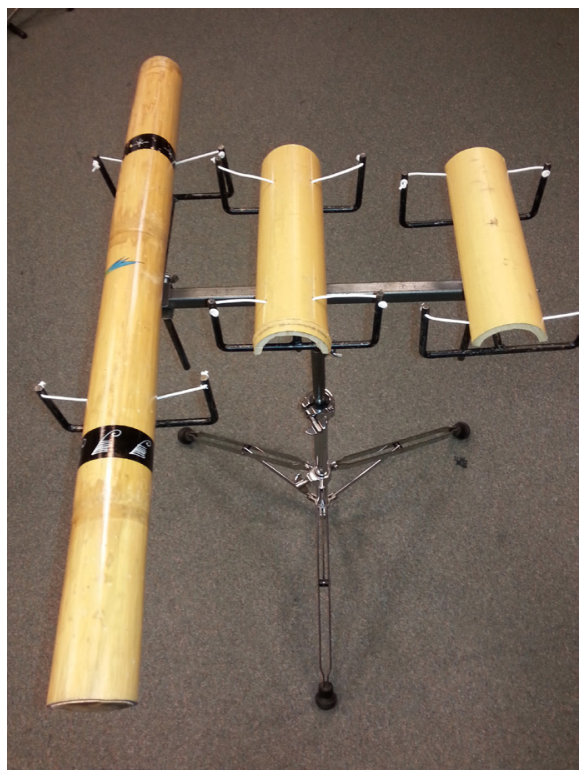

Fig. 3. A piece of bamboo. 
The music of the 11th station was based on the wooden sounds, generated by the wooden bells and the bamboo blocks. Its characteristic feature is the simplification of the texture and onomatopoeism. Single strikes on the bamboo blocks symbolize the accompanying sound of nailing the condemned to the cross. As Jagna Dankowska, professor of philosophy at the Fryderyk Chopin University of Music in Warsaw observes, "sharp ascetic sonic interventions break [...] lamentation music, thus referring to the old tradition of paschal planets (Latin planctus - the beating of the breast in mourning $)^{14}$. It is worth noting that the analyzed part remains in opposition to the previous part, in terms of the sound layer as well as the energy emitted by it.

\section{Station XII - Jesus dies on the cross}

The fire was burning, the glow come from afar

Darkness clashed with light;

The earth trembled, the wind raged,

When God was dying!

The bush burned with fire! - God was not in the bush!

God was not in the fire! -

In the cloud! - the breath of air!

In the wind! - the thunder! - in pain

The tears the body apart! -

God was absent,

When God was dying!

The fire was burning, the glow come from afar

Darkness clashed with light;

The earth trembled, the wind raged,

When God was dying!

12th's station tells the story of the death of Jesus on the cross. The central part of the mystery through which redemption is done is presented without pathos. The silent suffering reconciled to the Savior's own fate was expressed by the sound of the chorus performed on the bass. Following successive free chords made with soft tricks using the tremolo technique, they are kept at low dynamic values. Occasional slight volume swings, in the form of delicate crescend, imitate the

14 J. Dankowska, booklet attached to Carmina Crucis; ed. DUX, Warsaw, 2002, p. 37 . 
breath of a dying condemned man - measured, quieter and quieter. The musicality underlying the contemplative nature of this part makes it seem as if Jesus' death had ended with the whole of creation, time and space.

When navigating the harmonic aspect of the 12th Carmina Crucis station, it should be noted that the marimba chords are identical in structure to those found in the last part of the cycle - they are based on the Messaenian second modus.

\section{3th Station - The body of Jesus is} taken down from the cross

"In this time of great need

God I am looking for you -

Ease my pain!

My soul feels so heavy...

Thy will be done in eart,

As it is in heaven!"

„The cross bend your arms -

I, the mother in mourning,

Beseech you: Return me my son,

My only hope

Who in your hard embrace

For the sinner gave his life!"

Beloved mother,

Entreat God,

Now so far away,

that no blasphemer

From my land, nor my heart

The sign of your Son's Passion

Could fear forever out!

Taking downe of Jesus from the cross is accompanied by music performed on the Tibetan plates, Japanese gongs, windy bells, various varieties of plates. Sonorism of this part is compounded by the fact of using the pedal boiler as a resonator - some of the percussion idioms are placed on its diaphragm. At the moment of induction, the drummer changes the tension of the boiler membrane, which in turn implies a change in the color of the instruments resting on it. Of particular note is the fact that all of the idiophones used in this part are 
made of metal. Their sound is therefore a kind of musical glorification of Jesus and a proclamation of the future resurrection.

\title{
14th Station - Jesus is laid in the tomb
}

\author{
Effatha! - \\ Open up the Earth, \\ The bridegroom is coming! \\ (Among flowers - thorns in his hair). \\ Today on all your graves \\ As on the beloved temples \\ The heavens lay their kiss.
}

The analyzed work is topped with marimboc toccata, harmonic similar to the harmony of 12 th station, and melodic and rhythmic drawing analogous to its first part.

The claw construction of Carmina Crucis can be read as a symbol of a path leading from God, passing through the meanders of suffering, sacrifice, and finally returning to God. Mentioned in the work of prof. Jagna Dankowska sees this as follows:

The path begins and ends at the same musical point, symbolizing the inevitability of suffering in the way of the life of the God-Man, in a way repeated in different dimensions in the life of every human being. Jesus asked Thomas: "How can we know the way?" answers:

"I am the way, the truth and the life."

\section{The arrangement of executive space, syncretism}

As it was noted in the beginning of my work, Carmina Crucis is a syncretic composition combining the image, poetry and music. In this chapter I would like to expand this thread based on my executive and perceptual experiences.

The percussive mystery of the Passion of Christ can be realized in two ways. The first one, which does not require a longer description at the same time, it is a concert performance, assuming the realization of individual parts without poetic recitation and additional visual effects. The projection of the work using all the non-musical parameters of the work deserves a separate reflection:

a) recited poetry - in the original form described in this paper, each part of Carmina Crucis precedes the poetic text from the poem Droga by Andrzej Zieliński. It is recited by two actors - a woman 
and a man ${ }^{15}$. In later versions of the compositions, the lyrics were changed to Ernest Bryll's cycle of poems Golgota jasnogórska performed by one actor ${ }^{16}$. Actors / actor do not move while performing the work; they comment on passion events with poetry.

b) lighting - fourteen parts of the composition are distributed throughout the church in such a way as to allow the drummer to wander. Each of the stations is illuminated by candlelight, standing before the percussion installation. Thus the work is performed in partial darkness, broken by the splendor of successive stations.

c) graphics - the work is accompanied by a graphic exhibition by the professor of the Academy of Fine Arts in Warsaw - Marian Nowiński, depicting successive parts of the Way of the Cross.

\section{Contemporary implications}

Carmina Crucis is a pioneering work that introduces percussion instruments into the sacred space of the Christian temple. Making the percussion medium of artistic expression about spiritual roots, referring in the nearer or further perspective to the last moments of the life of Jesus resulted in compositions oscillating around similar themes in the 21 st century. Two monumental works by Ignacy Zalewski - Missa sine nomine (2017) and Stabat Mater (2017/18) deserve special attention in this respect.

The first of these compositions is dedicated to the choir, 4 trombones and percussion. The composer's assumption was to show the rite of Mass. understood from the perspective of simple people. For this reason, in addition to the canonical texts of the Ordinarium and the Proprium Missae, we will find, among others, poems by Józef Czechowicz, Adam Mickiewicz, Jan Kasprowicz. The drum performs two essential functions in the composition: sonorist (the composer draws special attention to the color effects of membranes and wood and metal idiophones) and rhythmic (narrative).

Zalewski's second work to be mentioned in the context of percussive lentimental considerations is Stabat Mater, for multiplexing, soprano, white choir and chamber ensemble. According to the composer's intent, the work focuses on the human perception of the pain of Jesus and Mary, thus making it necessary to make a new translation of the Latin

15 Texts of Andrzej Zieliński's Droga were performed by the actors of Teatr Adekwatny - Magdalena Teresa Wójcik and Henryk Boukołowski. 
sequence ${ }^{17}$. The original, fully authored work will be presented to the audience during the next edition of the Gorzkie Żale Festival in 2018.

The composer talks about his new work as follows:

Stabat Mater, a stage proto with prologue on white female solo voice, solo drum, mixed choir and instrumental ensemble is an attempt to look at the human aspects of maternal suffering - also in the context of the inconceivability of the plan in which this suffering is inscribed. The reason for reflection and new feelings will be the text given in the new translation, classical philologist Mateusz Żaboklicki. The core of the song is the sequence of the Stabat Mater, but it is preceded by the prologue of Jesus' conversation with Pilate, giving the suffering of the Virgin Mary (the main heroine of the work) direct meaning both human and purely musical or stage. The part of Jesus is silent - for His Kingdom is not out of this world. There was a multipurpose treatment virtuoso. The Cantata conceptually largely relies on the essay Pilate and Jesus by Giorgio Agamben, the mystery of John of the Cross (the idea of the „dark night” of the soul), and the presentation of the relationship Jesus - Pilate - Our Lady - World (people) as a sequence of mutual misunderstanding - at the humanly level, that in his inevitability, gives birth to pain and suffering, and is at the same time one of the most important secrets of religion. And the attempt to touch mysticism, the founding mysteries for the human perception of the world, the Good and the Evil, the beauty and self, is one of the deeper and more important creative challenges that have been taking place since the dawn of $\operatorname{art}^{18}$.

\section{Conclusion}

To summarize what has been said so far, it should be stated that the analyzed composition of Stanisław Moryto is a work of searching for transcendence on many levels.

One is the ground of faith, leading to the meeting of God with a man. Another is the ground of metaphysical reflection on human life and self-sacrifice for others. The multifacetedness of Carmina crucis is centered around the way literally interpreted as the passage of the God-man from the prairie of the Roman governor of Judea to Golgotha, or in a portable way where the way is understood as a transition leading to inner transformation, sanctification, knowledge of God and

$17 \quad$ Stabat Mater's new translation was made by Mateusz Żaboklicki.

18 Source of the quotation: the author's interview with the composer, conducted on 17.09.2017. The content of the interview is authorized by Ignacy Zalewski. 
self-knowledge. The way and inner transgression symbolizes the cross of Jesus - a soteriological artifact that condenses every form of human suffering leading to salvation.

"And next to the cross of Jesus" - crosses of unbelief, loneliness, fear and betrayal. Painful secrets of the human heart. Pride, contempt, hatred and humanity. Next - the crosses of those who "rush" and those "forced". Lack of indifference with the hand of God transformed into stations of joyful meeting. And the crosses of love and truth - the crosses of those who suffer with Christ. Glorious secrets. Stations giving testimony about God and man. And all this - around one path that goes from God and leads to God - bears like the beads of the gigantic rosary of human reality ${ }^{19}$.

\section{PERKUSYJNE ROZWAŻANIA MĘKI PAŃSKIEJ}

Pośród wielu gatunków muzycznych jedno z najważniejszych miejsc zajmuje pasja. Rozważania Męki Pańskiej czynione za pomocą rozmaitych środków wyrazu, przez wiele lat koncentrowały się wokół dwóch dzieł Jana Sebastiana Bacha - Pasji wg Św. Jana i Pasji wg. Św. Mateusza - będących oryginalnymi i głębokimi muzycznymi interpretacjami tego gatunku. W wieku XX do pasyjnej tradycji odwoływali się najwięksi kompozytorzy, w śród nich Krzysztof Penderecki (Passio et mors Domini Nostri lesum Christi secundum Lucam, 1966), Paweł Mykietyn (Pasja wg Św. Marka, 2008), rozszerzając arsenał muzycznych środków wyrazu na miarę XX-wiecznej ekspresji. Kompozytorzy współcześni wprowadzili do muzyki pasyjnej m.in. instrumenty perkusyjne, których brzmienie od zarania dziejów związane było z rozmaitymi formami sacrum. Niniejszy artykuł traktuje o Carminie Crucis Stanisława Moryto - dziele, w którym dźwięki rozbudowanych zestawów perkusyjnych opowiadają o męce Jezusa Chrystusa. Autor - czynny perkusista, oprócz analizy poszczególnych części cyklu wiele uwagi poświęca zagadnieniom wykonawczym, przedstawiając czytelnikom gotowe rozwiązania techniczne i interpretacyjne.

Słowa kluczowe: pasja, Stanisław Moryto, perkusja, droga.

\section{Bibliography:}

1. Badde P., Boskie Oblicze. Całun z Manoppello; ed. Polwen; Radom, 2006

2. The Bible, ed. Pallotinum, Poznań, 2003

3. Dankowska J., Zieliński A., booklet attached to Carmina Crucis; ed. DUX, Warsaw, 2002

19 A. Zieliński, booklet attached to Carmina Crucis; ed. DUX, Warsaw, 2002, p. 4. 
4. Eliade M., Historia wierzeń i idei religijnych; vol. I; transl. S. Tokarski, A. Kuryś; PAX Publishing Institute, Warsaw 1994-1997

5. M. Hart, Stevens J., Drumming at the edge of magic, Harper Collins Publisher, New York 1990.

6. Hoppal M., Eurasian Shaman, ed. Sparks 2009.

7. Hussey J.M., The Orthodox Church in the Byzantine Empire, Oxford, 1986.

8. Maffit R., Rhythm \& Beaty, the art of percussion, Watson-Guptill Publications, New York 1999

9. Metzner R., Ayahuasca - święte pnącze duchów, ed. Okultura, Warsaw, 2013

10. Metzner R., Teonanacatl. Święte grzyby, ed. Okultura, Warsaw 2013

11. Mikolajko A., Doświadczanie transcendencji poprzez muzykę, [in]: Rytuat $i$ transgresja w sztuce perkusyjnej, ed. L. Lorent, Chopin University Press, Warsaw 2017. 